\title{
GAMBARAN KADAR SGPT (SERUM GLUTAMIC PYRURIC TRANSMINASE) DAN SGOT (SERUM GLUTAMIC OXALOACETIC TRANSMINASE) PADA PASIEN TB-MDR (TUBERCULOSIS MULTIDRUG RESISTAN) DI RSUD LABUANG BAJI MAKASSAR
}

\author{
Tuty Widyanti' ${ }^{1)}$, Darmawaty Rauf ${ }^{1)}$, Lulu Lessy ${ }^{1)}$ \\ 1) Politeknik Kesehatan Muhammadiyah Makassar \\ Alamat korenspondensi:widyantituty@gmail.com
}

\begin{abstract}
ABSTRAK
Penelitian ini dilatarbelakangi karena adanya pengobatan pasien Tuberkulosis Multidrug Resistant (TB-MDR) yang berlangsung dengan jangka waktu yang lama yaitu selama 18-24 bulan sehingga dapat menimbulkan efek samping. Salah satu efek samping yang terjadi adalah hepatotoksisitas pada pasien TB-MDR karena terapi dengan OAT dapat mempengaruhi hati. Oleh sebab itu, perlukaan hati karena obat sangat mungkin terjadi, sehingga menyebabkan kadar SGPT dan SGOT dalam darah menjadi tinggi. Penelitian ini menggunakan Fotometer Chemistry Analyzer Cobas $C$ 311 dengan metode spektrofotometri yaitu pengukuran penyerapan sinar akibat interaksi sinar yang mempunyai panjang gelombang tertentu dengan larutan atau zat warna yang dilewati. Pada penelitian tentang gambaran kadar SGPT dan SGOT pada Pasien TB-MDR (Tuberculosis Multidrug Resistant) di RSUD Labuang Baji Makassar sebanyak 17 sampel diperoleh kadar SGOT yaitu 13 sampel menunjukkan batas normal dan 4 sampel menunjukkan peningkatan yang melebihi nilai normal, sedangkan utnuk kadar SGPT yaitu 16 sampel menunjukkan batas normal dan 1 sampel menunjukkan peningkatan yang melebihi nilai normal. Dapat disimpulkan bahwa terjadinya peningkatan kadar SGPT dan SGOT pada Pasien TB-MDR yaitu akibat pemberian OAT dalam jangka waktu yang lama

Kata kunci: TB-MDR, Hepatotoksisitas, SGOT dan SGPT, spektrofotometri
\end{abstract}

\begin{abstract}
This research is motivated because the treatment of multidrug resistant tuberculosis patients (MDR TB) that lasted for a long period of time for 18-24 months so that they could cause side effects. One side effect that occurs is hepatotoxicity in MDR-TB patients because therapy with OAT can affect the liver. Therefore, liver injury due to drugs is very likely to occur, causing SGPT and SGOT levels in the blood to be high. This study used a Cobas C 311 Photometer Chemistry Analyzer with a spectrophotometric method, which is the measurement of light absorption due to light interactions that have a certain wavelength with the solution or dye being passed. In a study of the picture of SGPT and SGOT levels in 17 MDR (Multidrug Resistant Tuberculosis) Patients in Labuang Baji Makassar Hospital, 17 samples were obtained SGOT levels, 13 samples showed normal limits and 4 samples showed an increase that exceeded normal values, while SGPT levels were 16 samples showed normal limits and 1 sample showed an increase that exceeded the normal value. It can be concluded that the increase in SGPT and SGOT levels in MDR-TB patients is due to the administration of OAT for a long time.
\end{abstract}

Keywords: MDR-TB, Hepatotoxicity, SGOT and SGPT, Spectrophotometry

Jurnal Medika: Media Ilmiah Analis Kesehatan Volume 4 Nomor 1, Juni 2019 ISSN: 2540-7910 


\section{PENDAHULUAN}

Tuberkulosis paru adalah penyakit tuberkulosis yang menyerang paru yang disebabkan oleh kuman tuberkulosis (Mycrobacterium tuberculosis). Penderita tuberkulosis paru BTA posiitif adalah penderita tuberkulosis paru yang sputumnya mengandung kuman tuberkulosis. Penderita tuberkulosis paru BTA positif merupakan sumber penularan karena kemampuannya menularkan penyakit ini setiap saat kepada orang lain sehingga dianggap bermasalah secara epidemiologi. (Tandi. J, 2010).

World Health Organization (2010) melaporkan bahwa jumlah penderita tuberkulosis di Indonesia sebesar 429 ribu orang dan Indonesia berada pada peringkat kelima dengan jumlah terbesar insiden kasus tuberkulosis didunia. Dengan penduduk lebih dari 200 juta orang, Indonesia menempati ururtan kelima setelah India, China, Afrika Selatan, dan Nigeria dalam hal jumlah penderita di antara 22 negara dalam masalah tuberkulosis terbesar di dunia. Hal tersebut disebabkan oleh karena kegagalan pengobatan. (Depkes RI, 2009).

Pengobatan yang terputus ataupun tidak sesuai dengan standar DOTS (Directly Observed Treatment, Shortcourse chemotherapy) juga dapat berakibat pada munculnya kasus kekebalan multi terhadap obat anti TB yang memunculkan jenis kuman TB yang lebih kuat, yang dikenal dengan Multidrug Resistant (TB-MDR). Pengobatan TBMDR membutuhkan biaya yang lebih mahal dan waktu yang lebih lama dengan keberhasilan pengobatan yang belum pasti (Depkes RI, 2009).

Masalah TB-MDR sudah menjadi masalah global sehingga diperlukan strategi penanganan yang terarah dan tepat supaya bisa mengurangi masyarakat terkena TB-MDR. TB-MDR adalah resistensi kuman Mycobacterium tuberculosis terhadap Obat Anti Tuberculosis (OAT) yang terdiri dari isoniazid dan rifampisin (Depkes RI,
2010)

Morbiditas dan mortalitas akibat tuberkulosis merupakan permasalahan serius terutama akibat timbulnya efek samping Obat Anti Tuberkulosis (OAT). Efek samping OAT yang paling serius adalah hepatotoksik. (Sari et al. 2014).

Hepatotoksisitas akibat OAT menyebabkan cedera hati yang luas dan permanen serta dapat menyebabkan kematian jika tidak terdeteksi pada tahap awal. Selain hepatotoksisitas, OAT juga dapat menyebabkan sirosis, kanker hati, dan berujung pada kematian. (Kumar et al. 2014).

Menurut American Association for the Study of Liver Disease (AASLD) menetapkan bahwa parameter untuk menentukan ada atau tidaknya kerusakan hati adalah dengan melihat kadar Alanin aminotransferase (ALT)/Serum Glutamic Pyruric Transaminase (SGPT) yang meningkat lebih dari tiga kali batas atas normal dan peningkatan bilirubin total lebih dari dua kali batas atas normal. Peningkatan enzim hati Aspartat aminotransferase (AST)/Serum Glutamic Oxaloacetic Transaminase (SGOT) juga dianggap sebagai indikator kerusakan hati. ( I.L.M dan I.H, 2014).

Pada penelitian yang dilakukan sebelumnya dari 339 pasien yang diberi pengobatan dengan anti tuberkulosis, 67 pasien mengalami kenaikan SGPT dan SGOT. Dari 67 pasien tersebut, 38 pasien mengalami peningkatan kadar SGOT 3-5 kali batas normal, 15 pasien meningkat 1015 kali batas normal, dan 14 pasien meningkat lebih dari 10 kali batas normal. Sedangkan pada kadar SGPT sebanyak 38 pasien meningkat 2-5 kali batas normal, 15 pasien meningkat 5-10 kali batas normal, dan 14 pasien meningkat lebih dari 10 kali batas normal (Mahmood et.al, 2007). Berdasarkan uraian latar belakang tersebut, maka peneliti tertarik untuk melakukan penelitian Gambaran Kadar SGPT dan SGOT pada Pasien Tuberkulosis Multidrug Resistant di RSUD Labuang Baji Makassar. 


\section{METODE PENELITIAN Alat dan Bahan}

Alat yang digunakan dalam penelitian ini adalah torniquet, spoit, tabung vakum tutup merah, rak tabung, mikro pipet, tip biru, sentrifuge, cup sampel dan fotometer Chemistry Analyzer Cobas C 311.

Bahan yang digunakan dalam penelitian ini adalah kapas alkohol $70 \%$, sampel serum, reagen SGPT, dan reagen SGOT.

\section{Prosedur Kerja}

\section{Pengambilan Darah Vena}

Dipilih bagian yang akan dilakukan tusukan yaitu dipilih vena yang besar dan tidak mudah bergerak (vena mediana cubiti). Kemudian desinfektan area vena mediana cubiti dengan kapas alkohol dengan gerakan memutar dari tengah ke tepi, dibiarkan selama 30 detik untuk pengeringan alkohol. Setelah itu, dipasang tourniquet $7,5-10 \mathrm{~cm}$ diatas bagian vena mediana cubiti disertai pengepalan tangan pasien untuk membantu penampakan vena. Lalu ditusuk jarum ke dalam vena menggunakan spoit, posisi lubang jarum menghadap keatas dengan sudut $15-30^{\circ}$. Setelah darah mengalir tourniquet dilepas lalu dilepaskan jarum perlahan-lahan dan segera ditekan dengan kapas selama 3-5 menit. Darah yang telah diambil dimasukkan kedalam tabung vakum tutup merah dan bolak balik tabung 5-10 kali. Diplaster bagian vena mediana cubiti kemudian beri label pada tabung (nama, nomor laboratorium, jam dan tanggal pengambilan) (Ridjayani, 2015).

\section{Proses mendapatkan serum}

Tabung vakum yang berisi darah tersebut dibiarkan dalam suhu ruangan selama beberapa menit lalu disentrifuge dengan kecepatan 3000 rpm selama 3-5 menit. Setelah disentrifuge darah akan terpisah dengan serum. Serum yang dihasilkan segera dipisahkan dari bekuannya. Serum yang akan diperiksa yaitu serum yang tidak haemolisis.

Prosedur pengoprasian alat fotometer Cobas C 311 full automatik dan pemeriksaan sampel

Serum pasien dipipet kedalam kuvet sebanyak $200 \mu \mathrm{L}$, diletakkan pada disk posisi pada sampel disk. Pada layar monitor pilih workplace kemudian dipilih test selection lalu dipilih routine $(N)$. Dimasukkan sequence no sampel sesuai disk position pada sampel disk. Kemudian masukkan sampel ID pasien. Lalu dipilih jenis tes yang akan diperiksa tekan save. Selanjutnya diulangi langka 1-4 untuk sampel yang lain. Kemudian diklik start. (Sumber : Laboratorium RSUD Labuang Baji Makassar).

\section{Interpertasi Hasil}

Nilai normal SGOT/AST :

Laki-Laki : 10-40 U/L, Perempuan : 9-25

$\mathrm{U} / \mathrm{L}$

Nilai Normal SGPT/ALT :

Laki-Laki : 10-55 U/L, Perempuan : 7-30

$\mathrm{U} / \mathrm{L}$

(Sumber : Laboratorium RSUD Labuang Baji Makassar)/Cobas C 311.

Analisis Data

Analisa data disajikan dalam bentuk tabel dan dinarasikan

\section{HASIL DAN PEMBAHASAN}

Berdasarkan penelitian gambaran kadar SGPT dan SGOT pada penderita TB-MDR (Tuberculosis Multidrug Resistant) di RSUD Labuang Baji Makassar diperoleh data sebagai berikut : 
Tabel 1. Hasil pemeriksaan kadar SGPT dan SGOT pada Pasien TB-MDR di RSUD Labuang Baji Makassar

\begin{tabular}{|c|c|c|c|c|c|c|c|}
\hline $\begin{array}{c}\text { Kode } \\
\text { Sampel }\end{array}$ & $\begin{array}{l}\mathbf{J} \\
\mathbf{K}\end{array}$ & $\begin{array}{l}\text { Umur } \\
\text { (Thn) }\end{array}$ & $\begin{array}{c}\text { Lama } \\
\text { pengobatan } \\
(B \ln )\end{array}$ & $\begin{array}{c}\text { Kadar } \\
\text { SGOT } \\
(\mathbf{U} / \mathrm{L})\end{array}$ & Ket & $\begin{array}{c}\text { Kadar } \\
\text { SGPT } \\
(\mathbf{U} / L) \\
\end{array}$ & Ket \\
\hline $\mathrm{A}$ & $\mathrm{L}$ & 36 & 20 & 33 & Normal & 17 & Normal \\
\hline B & $\mathrm{L}$ & 57 & 24 & 20 & Normal & 12 & Normal \\
\hline $\mathrm{C}$ & $\mathrm{L}$ & 48 & 20 & 15 & Normal & 16 & Normal \\
\hline $\mathrm{D}$ & $\mathrm{L}$ & 51 & 10 & 37 & Normal & 27 & Normal \\
\hline $\mathrm{E}$ & $\mathrm{P}$ & 22 & 24 & 34 & Meningkat & 11 & Normal \\
\hline $\mathrm{F}$ & $\mathrm{P}$ & 42 & 20 & 18 & Normal & 12 & Normal \\
\hline G & $\mathrm{P}$ & 38 & 10 & 27 & Normal & 16 & Normal \\
\hline $\mathrm{H}$ & $\mathrm{L}$ & 40 & 10 & 30 & Normal & 30 & Normal \\
\hline I & $\mathrm{L}$ & 56 & 10 & 23 & Normal & 17 & Normal \\
\hline $\mathrm{J}$ & $\mathrm{L}$ & 47 & 10 & 26 & Normal & 25 & Normal \\
\hline $\mathrm{K}$ & $\mathrm{L}$ & 45 & 20 & 122 & Meningkat & 20 & Normal \\
\hline $\mathrm{L}$ & $\mathrm{L}$ & 37 & 10 & 63 & Meningkat & 36 & Normal \\
\hline M & $\mathrm{L}$ & 66 & 11 & 33 & Normal & 24 & Normal \\
\hline $\mathrm{N}$ & $\mathrm{P}$ & 51 & 20 & 15 & Normal & 9 & Normal \\
\hline $\mathrm{O}$ & $\mathrm{L}$ & 43 & 09 & 2455 & Meningkat & 241 & Meningkat \\
\hline $\mathrm{P}$ & $\mathrm{P}$ & 38 & 09 & 21 & Normal & 19 & Normal \\
\hline $\mathrm{Q}$ & $\mathrm{L}$ & 48 & 09 & 42 & Normal & 46 & Normal \\
\hline
\end{tabular}

Tabel 2. Rekapitulasi kadar SGPT dan SGOT berdasarkan Jenis Kelamin pada Pasien TB-MDR di RSUD Labuang Baji Makassar

\begin{tabular}{ccccc}
\hline Jenis Kelamin & $\begin{array}{c}\text { SGOT } \\
\text { Normal }\end{array}$ & $\begin{array}{c}\text { SGOT } \\
\text { Meningkat }\end{array}$ & $\begin{array}{c}\text { SGPT } \\
\text { Normal }\end{array}$ & $\begin{array}{c}\text { SGPT } \\
\text { Meningkat }\end{array}$ \\
\hline Laki - Laki & 9 & 3 & 12 & 1 \\
Perempuan & 4 & 1 & 4 & - \\
Total & 13 & 4 & 16 & 1 \\
\hline
\end{tabular}

Tabel 3. Persentase Kadar SGOT dan SGPT pada pasien TB-MDR di RSUD Labuang Baji Makassar.

\begin{tabular}{cccc}
\hline Parameter & Normal & Meningkat & Total \\
\hline \multirow{2}{*}{ SGOT } & 13 Sampel & 4 sampel & $100 \%$ \\
& $(76.5 \%)$. & $(23.5 \%)$ & \\
SGPT & 16 sampel & 1 sampel & $100 \%$ \\
& $(94.1 \%)$ & $(5.9 \%)$ & \\
\hline
\end{tabular}

Hasil penelitian dari pemeriksan kadar SGPT dan SGOT menggunakan fotometer Chemistry Analyzer Cobas C 311 metode spektrofotometri diperoleh kadar SGOT sebanyak dan 13 sampel menunjukkan batas normal antara lain pada jenis kelamin laki-laki 9 sampel dan pada perempuan 4 sampel dengan persentase $76.5 \%$, dan 4 sampel menunjukkan peningkatan yang melebihi nilai normal antara lain pada jenis kelamin laki-laki meningkat3 sampel antara lain : pada kode sampel $\mathrm{K}$ hasilnya $122 \mathrm{U} / \mathrm{L}$, pada kode sampel L hasilnya $63 \mathrm{U} / \mathrm{L}$, pada kode sampel O hasilnya $2455 \mathrm{U} / \mathrm{L}$ danpada perempuan meningkat 1 sampel yaitu pada kode sampel E hasilnya $34 \mathrm{U} / \mathrm{L}$ dengan persentase $23.5 \%$. Nilai normal kadar 
SGOT pada laki-laki: $10-40$ U/L dan Perempuan : 9-25 U/L.

Dari Hasil penelitian diperoleh kadar SGPT sebanyak 16 sampel menunjukkan batas normal antara lain pada jenis kelamin laki-laki 12 sampel dan pada perempuan 4 sampel dengan persentase $94.1 \%$, dan 1 sampel menunjukkan peningkatan yang melebihi nilai normal antara lain pada jenis kelamin laki-laki meningkat1 sampel yaitu pada kode sampel O hasilnya $245 \mathrm{U} / \mathrm{L}$ dan pada perempuan tidak ada peningkatan dengan persentase $5.9 \%$. Nilai normal kadar SGPT pada laki-laki: 10-55 U/L dan perempuan: 7-30 U/L.

Hepatotoksitas dapat didefinisikan sebagai kerusakan hatidisebabkan oleh obat-obatan. Dari hasil penelitian didapatkan Hepatotoksistas dibagi menjadi tiga grade yaitu, kelompok nilai SGOT 51-125 U/L (hepatotoksisitas grade I/ringan) sebanyak 2 sampel antara lain pada kode sampel K hasilnya $122 \mathrm{U} / \mathrm{L}$ dan Kode sampel L hasilnya 63 U/L, kelompok nilai SGOT 126-250 U/L (hepatotoksisitas grade II/sedang) tidak ada dan kelompok nilai $\mathrm{SGOT} \geq 250 \mathrm{U} / \mathrm{L}$ (hepatotoksisitas grade III/berat) sebanyak 1 sampel yaitu pada kode sampel O hasilnya $2455 \mathrm{U} / \mathrm{L}$. Namun pada kode sampel E hasilnya 34 U/L dikategorikan meningkat tapi tidak masuk kedalam kategori hepatotoksistas grade I/II/II. Sedangkan untuk kelompok nilai SGPT 151-300 U/L (hepatotoksisitas grade II) hanya ada pada 1 sampel yang beri kode sampel $\mathrm{O}$ hasilnya $241 \mathrm{U} / \mathrm{L}$. Untuk Pasien dengan kode sampel $\mathrm{O}$ mengalami nekrosis sel hati karena pada data pemeriksaan faal hati sebelumnya diperoleh hasil kadar SGPT dan SGOT normal dan pasien juga tidak mempunyai riwayat penyakit lainnya.

Dari hasil penelitian didapatkan bahwa pasien TB-MDR yang mengalami hepatotoksisitas berdasarkan kadar SGOT pada kelompok umur 37-45 tahun yaitu sebanyak 3 orang dan hepatotoksisitas berdasarkan kadar SGPT pada umur 43 tahun yaitu 1 orang. Pada penelitian
Govindan (2011) juga menyatakan yang mengalami hepatotoksisitas ringan 6 orang terjadi pada umur 40-60 tahun dan penyebabnya karena peningkatan umur. Pada penelitian Khadka (2007) juga menyatakan kelompok umur terbanyak mengalami hepatotoksisitas adalah 41-60 tahun sebanyak 14 pasien $(45,1 \%)$, semakin meningkatnya umur, semakin tinggi resiko terjadinya hepatotoksisitas karena fungsi hati akan menurun seiring dengan peningkatan umur sehingga terjadi penurunan clearance obat yang dimetabolisme oleh enzim CYP450 dan juga terjadi perubahan pengaliran darah di hati dan perubahan size hati dengan meningkatnya umur.

Dari hasil penelitian juga didapatkan bahwa kejadian hepatotoksisitas lebih banyak dialami oleh laki-laki dibandingkan perempuan. Menurut beberapa penelitian lain menyebutkan bahwa laki-laki lebih rentan terkena TB karena berkaitan dengan kebiasaan merokok, sehingga sistem imun menurun. Selain itu juga laki-laki kurang memperhatikan kesehatannya dan kebiasaan sehari hari yang lebih banyak berada diluar rumah sehingga resiko terpapar dengan $M$. tuberculosis dari penderita TB lain lebih besar. Sehingga kejadian pengobatan TB-MDR lebih banyak terjadi pada pria.

Selain peningkatan kadar SGPT dan SGOT yang dipengaruhi oleh faktor usia dan jenis kelamin, beberapa faktor yang dapat meningkatkan resiko peningkatan SGPT dan SGOT antara lain aktivitas fisik berlebihan, mengonsumsi alkohol, penyakit hati lainnya dan obat. Salah satu obat yang dapat menyebabkan SGPT dan SGOT tinggi terhadap pasien TB-MDR yang mengonsumsi obat anti tuberkulosis yaitu pirazinamid. Meskipun mekanisme hepatotoksik pirazinamid sampai saat ini belum diketahui. Pirazinamid diketahui menyebabkan iskemik sel hati.

Menurut Peraturan Menteri Kesehatan Republik Indonesia Nomor 13 Tahun 2013 Tentang Pedoman 
Manajemen Terpadu Pengendalian Tuberkulosis Resistan Obat, terdapat beberapa obat OAT yang kemungkinan menyebabkan kelainan fungsi hati antara lain, Etionamid, PAS, dan Etambutol. Hal ini menunjukkan bahwa pemberian Obat Anti Tuberculosis (OAT) jangka panjang bisa berpengaruh pada peningkatan kadar SGPT dan SGOT pada pasien TB-MDR dalam masa pengobatan, sedangkan pada pasien yang dengan kadar normal tergantung pada respon imun masingmasing setiap pasien serta status gizi pasien.

Efek samping OAT pada pengobatan pasien TB-MDR yang berkepanjangan dapat diatasi dengan melakukan pemantauan kondisi klinis pasien selama menjalani terapi sehingga efek samping dari ringan sampai berat dapat segera diketahui dan ditatalaksanakan secara tepat.

\section{DAFTAR PUSTAKA}

Depkes RI. 2009. Pedoman Nasional Penanggulangan Tuberkulosis. Jakarta: Gerdunas-TB.

Depkes RI. 2010. Petunjuk Teknis Penatalaksanaan Pasien TBMDR. Jakarta.

Kumar S, Ambree K, Sharma R, Sigh KP. Anti-tuberculosis drug induce hepatotxicity: a review. International Journal of Advance Biotechnology and Research. 2014; vol 5, issue 3, 423-437.13.

Mahmood K, Hussain A, Jairamani KL, Talib A, Abbasi BU, Salkeen

S. Hepatotoxicity with antituberculosis drugs: the risk factors. Pak J Med Sci. 2007;23(1):33-8.

Maria I L, Hasan I. Drug-induced liver injury-Tantangan dalam diagnosis. Departemen Ilmu Penyakit Dalam, Fakultas Kedokteran Universitas Indonesia. Jakarta; 2014.

Ridjayana DE. 2016. Penuntun Praktikum Hematologi. Akademi Analis Kesehatan Muhammadiyah : Makassar.

Sari I D, Yuniar Y, Ayarifuddin M. Studi Monitoring Efek Samping Obat Anti Tuberkulosis FDC kategori 1 di Provinsi Banten dan Provinsi Jawa Barat. Media Penelitian dan Pengembangan Kesehatan. 2014. Vol 4(01): 2835

Tandi. J, 2010. Farmasi Klinik. Jilid II. Stifa Pelita Mas Palu: Palu. 